\title{
Occurrence of microplastics on beach sediment at Libong, a pristine island in Andaman Sea, Thailand
}

\author{
Siriporn Pradit ${ }^{\mathrm{a}, \mathrm{b}, *}$, Prawit Towatana $^{\mathrm{a}, \mathrm{b}}$, Thongchai Nitiratsuwan ${ }^{\mathrm{c}}$, Suthep Jualaong ${ }^{\mathrm{d}}$, \\ Monticha Jirajarus $^{\mathrm{a}}$, Kittiwara Sornplang ${ }^{\mathrm{a}, \mathrm{b}}$, Prakrit Noppradit ${ }^{\mathrm{a}, \mathrm{b}}$, Yardtip Darakai ${ }^{\mathrm{a}}$, \\ Chaiyapruk Weerawong ${ }^{\mathrm{e}}$ \\ ${ }^{a}$ Marine and Coastal Resources Institute, Faculty of Environmental Management, Prince of Songkla \\ University, Songkhla 90110 Thailand \\ b Coastal Oceanography and Climate Change Research Center, Prince of Songkla University, Songkhla \\ 90110 Thailand \\ c Faculty of Science and Fisheries Technology, Trang Campus, Rajamangala University of Technology \\ Srivijaya, Trang 92150 Thailand \\ d Marine and Coastal Resources Research, the Eastern Gulf of Thailand, Department of Marine and \\ Coastal Resources, Thailand \\ e Mu Ko Libong Non-hunting Area, Department of National Parks, Wildlife and Plant Conservation, \\ Thailand
}

*Corresponding author, e-mail: siriporn.pra@psu.ac.th

Received 27 Jan 2020

Accepted 16 May 2020

ABSTRACT: Microplastic pollution is a global issue and a hot issue in Thailand. This is the first assessment of microplastics at Libong, a pristine island, located in Andaman Sea. The investigation was carried out by collecting the sediment from beach and mudflat areas of the island in May and July, 2019. Three class sizes of microplastics were determined: greater than $5 \mathrm{~mm}, 18$ pieces; $1-5 \mathrm{~mm}, 28$ pieces; and less than $1 \mathrm{~mm}, 129$ pieces. The total number of microplastics from beach sediment was greater than that from the mudflat sediment. The discovered microplastics were mainly constituted of fibers (59\%) and fragments (41\%). A great variety of colors were found, and white (43\% from beach, $41 \%$ from mudflat area) was the most common, followed by blue ( $9 \%$ from beach, 35\% from mudflat) and red (12\% from beach, $6 \%$ from mudflat). Polymers identified by Fourier Transform Infrared Spectrophotometer consisted of poly vinyl chloride (PVC), polypropylene (PP), Nylon, Polyethylene (PE), Polyester, Polyacrylate (PA) and polymer with a structure similar to EPDM rubber.

KEYWORDS: microplastic, FTIR, polymer, beach, mudflat, sediment

\section{INTRODUCTION}

Marine plastic waste has long been recognized as an environmental problem. As plastic pollution of marine ecosystems has become a widely acknowledged environmental problem, it has been placed on the agenda at the highest international levels [1]. Geyer et al [2] estimated that approximately 6300 million tons of plastic waste were generated between the years 1950 and 2015, and 4977 million tons of which were accumulated in landfills and the natural environment. The origin of microplastics is from a large piece of marine plastic waste under the influence of UV rays in sunlight $[3,4]$ and wave action breaking the plastic into small particles $[4,5]$. A small piece of plastic is called microplastic. This includes small plastic product that is primarily made as a scrub for cosmetic use [3,5]. Microplastics have been classified with different size ranges, varying from study to study, with diameters of $<10 \mathrm{~mm}$ [6], $<5 \mathrm{~mm}$ [7], $<2 \mathrm{~mm}[8]$ and $<1 \mathrm{~mm}[9,10]$. They easily spread to the environment, but it is difficult to handle or eliminate them. They are thus especially vulnerable for both land- and sea-based microplastic debris inputs, often exhibiting high numbers of microplastics [11]. Many researchers define microplastics as plastic particles that are smaller than 5 millimeters [3,4].

Microplastics are both abundant and widespread within the marine environment, which are found in their highest concentrations along coastlines and within mid-ocean gyres [12]. These microplastic particles have already been 
detected in environments, ranging from beach sediment and surface waters all around the globe to more remote locations such as deep sea sediments and arctic waters $[13,14]$. Among the abovementioned environmental compartments studied, beach sediments represent the interface between the ocean and terrestrial habitats [15].

Plastics are synthetic organic polymers, which are derived from the polymerization of monomers extracted from oil or gas [16]. Primary source of microplastics includes Polyethylene (PE), polypropylene (PP) and polystyrene (PS) particles in cosmetic and medical products. Secondary microplastics originate from physical, chemical and biological processes, resulting in fragmentation of plastic debris [8,17]. Using Fourier Transform Infrared Spectroscopy (FTIR), items of interest can then be confirmed as plastic by comparing spectra of the samples with those of known polymers $[18,19]$. The most commonly used and abundant polymers are high density polyethylene (HDPE), lowdensity polyethylene (LDPE), poly vinyl chloride (PVC), polystyrene (PS), polypropylene (PP) and poly(ethylene terephthalate) (PET), which together account for approximately $90 \%$ of the total plastic production worldwide [20].

For Thailand, very few previous studies on marine waste and microplastics in the environment and living organisms have been published such as Azad et al [21] conducting the study of microbiological contamination in the stomachs of economic fishes from the lower Gulf of Thailand. It was found that the plastic ingested by aquatic animals was $79.52 \%$ microplastics $(<5 \mathrm{~mm}$ ) and $20.48 \%$ mesoplastics (5-25 mm). According to the study result of Goh et al [22], the mean concentration of microplastic in these green mussel (Perna viridis) samples was $21.10 \pm 0.15$ items/g and $12.30 \pm 0.20$ items/individual. Microplastic studies in the beach ecosystem were still conducted in the limited areas usually in the beach with tourist attraction. Furthermore, the study results were not comprehensive and sufficient especially in areas that are islands which have the opportunity to be developed as a tourist destination in the future such as the Island of Libong, Thailand. Thus, this study result certainly provided the valuable information for fulfilling the background data of the aforementioned unique ecological system. Moreover, Libong Island is an important sea grass area of the Andaman coast with the water depth between $0.5-2.8 \mathrm{~m}$ of sea level [23]. This definitely makes it become important ecological area because it is the habitat of dugongs in Trang Province. Mi-

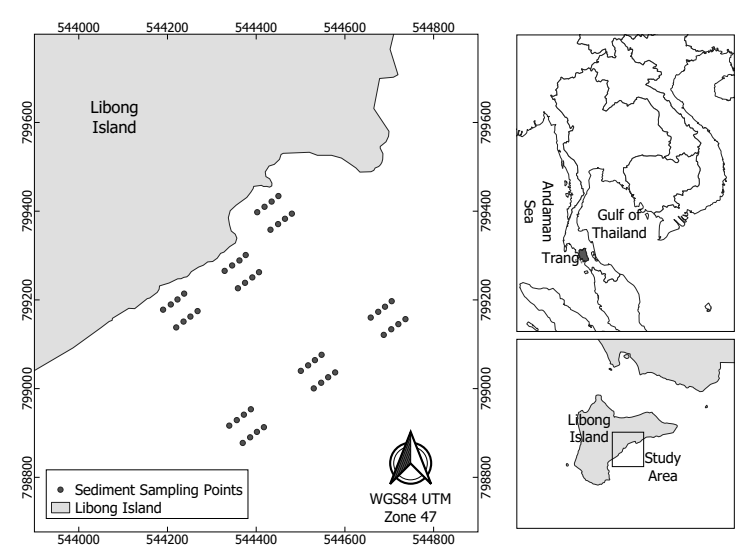

Fig. 1 Study area with the sampling sites at Libong Island, Thailand

crolight surveying around Trang Province between 15-23 November 2006 found 84 dugongs and their 25 offspring [24]. Furthermore, the abundant sea grasses around the Libong and Muk Islands are important food sources for the largest herd of dugongs in Thailand. Therefore, if there are some quantities of marine wastes and microplastics around the beach system of Libong Island, they may affect aquatic animals, dugongs and humans who consume the aquatic fauna and sea grasses contaminated with microplastics. Thus, the objective of this study was to study the microplastic contamination and their types in sand and mud beach ecosystems.

\section{MATERIALS AND METHODS}

\section{Study area}

Libong Island was selected for this study. It is a pristine island located in Andaman sea at latitude $07^{\circ} 14^{\prime}-07^{\circ} 17^{\prime} \mathrm{N}$ and longitude $99^{\circ} 22^{\prime}-09^{\circ} 27^{\prime} \mathrm{E}$ on the western coastline of Kantang District, Trang Province (Fig. 1). Libong Island has a diverse ecosystem, including sandy beach, mudflat next to the sand beach, coral reefs, mangrove forests and an extensive seagrass bed. The study site is situated on the east coast of the island where the large seagrass bed can be found. Libong Island is affected by monsoon winds as follows: (1) Southwest monsoon (SW) blows from the ocean to the southwest direction of the shore of the island around May to October or early November and makes heavy rain and strong wave to the island; (2) Northeast monsoon (NE) blows from the South China Sea and the Gulf of Thailand into the southeast of the southern Thailand region and blows to the northeastern of the island around November to April, making light rain and 
light wind.

\section{Collecting sediment samples}

Sampling of sediment samples was carried out at sand and mud beaches located at the Eastern site of the island, and there were villagers' houses at their head beaches. The 48 sampling points were selected for collecting the samples 2 times in May and July 2019 , which is a rainy season in this area. This study divided the found microplastics into 3 sizes including (1) larger than $5 \mathrm{~mm}$, (2) $1-5 \mathrm{~mm}$ and (3) smaller than $1 \mathrm{~mm}$.

Sediment samples were sampled along the coast by placing a $50 \times 50 \mathrm{~cm}$ quadrant frame in a $100 \times 100 \mathrm{~m}$ specimen block at the beachhead, the middle and the end of each beach with a distance of $100 \mathrm{~m}$ apart among the blocks; collecting sediment in the quadrant frame was carried out using a shovel by scooping about $10 \mathrm{~cm}$ depths and putting the samples in glass jars ( 5 replicates) per station before sending to laboratory for analysis.

\section{Analysis of microplastics in sediment samples}

The sediment samples were prepared for analysis by air drying and sieving through sieves with $1 \mathrm{~mm}$ and $5 \mathrm{~mm}$ apertures. The sediment that remained on the $5 \mathrm{~mm}$ sieve was weighed and sorted for the microplastics with the naked eye. Sediment between 1-5 $\mathrm{mm}$ was weighed and sorted for microplastics with the naked eye or collected for microscopic examination. The samples sieved through the $1 \mathrm{~mm}$ sieve were analyzed for microplastics using the modified method from NOAA Marine Debris Program [25]. The $400 \mathrm{mg}$ sieved sample was transferred to a $500 \mathrm{ml}$ beaker. About $100 \mathrm{mg}$ subsediment sample was weighed and oven dried at $90^{\circ} \mathrm{C}$ for $24 \mathrm{~h}$. Then, the dried sample was placed in a $1000 \mathrm{ml}$ beaker and stirred in $\mathrm{NaCl}$ solution to separate the debris or plastics by floating. After that, the sample was filtered through a $300 \mu \mathrm{m}$ filter cloth. The sample left on a $300 \mu \mathrm{m}$ filter cloth was taken to a $500 \mathrm{ml}$ beaker. Then, $20 \mathrm{ml}$ of ferrous sulfate and $20 \mathrm{ml}$ of $20 \%$ hydrogen peroxide were added, and chemical reaction was proceeded at room temperature for 5 minutes. Then, the sample was heated and stirred at the temperature controlled (not higher than $75^{\circ} \mathrm{C}$ ) in the fume hood and kept in a tall cylinder for 1 night. After that, the sample was filtered through GF/C filter paper and oven dried at $60^{\circ} \mathrm{C}$ for $3 \mathrm{~h}$. Then, the sample was examined under a stereo microscope at different magnifications to find microplastics.
Table 1 Microplastic found in beach sediment and mudflat sediment at Libong Island.

\begin{tabular}{lcccc}
\hline Sediment & Size & $\begin{array}{c}\text { 1st: No. } \\
\text { of pieces }\end{array}$ & $\begin{array}{c}\text { 2nd: No. } \\
\text { of pieces }\end{array}$ & $\begin{array}{c}\text { Occurrence } \\
\text { (pieces } / \mathrm{m}^{2} \text { ) }\end{array}$ \\
\hline Beach & $>5 \mathrm{~mm}$ & - & 18 & \\
Beach & $1-5 \mathrm{~mm}$ & 13 & 7 & \\
Beach & $<1 \mathrm{~mm}$ & 31 & 83 & \\
Total & & 44 & 108 & 25 \\
\hline Mudflat & $>5 \mathrm{~mm}$ & - & - & \\
Mudflat & $1-5 \mathrm{~mm}$ & 8 & - & \\
Mudflat & $<1 \mathrm{~mm}$ & - & 15 & \\
Total & & 8 & 15 & 4 \\
\hline
\end{tabular}

\section{Polymer identification}

About $40 \%$ of the total number of microplastics was used in this study. Samples was analyzed to identify polymer types, color and shape. To characterize and identify polymer types, the spectra of the potential polymer particles less than $1 \mathrm{~mm}$ were obtained from Fourier transform infrared (FTIR) spectrometer, Frontier model, coupled with Spotlight 200i FTIR microscope (Perkin Elmer, USA) whereas the potential samples with larger than $1 \mathrm{~mm}$ dimension were identified by using Frontier FTIR spectrometer with attenuated total reflection (ATR) technique. The spectra were identified by comparing with referent polymer spectra in the spectral library obtained from the FTIR program.

\section{RESULTS AND DISCUSSION}

\section{Microplastic contamination in the beach and mudflat area}

The total area of sampling area in this study was $120000 \mathrm{~cm}^{2}$, including $60000 \mathrm{~cm}^{2}$ each of sandy beach and mudflat area. For the 1st microplastic contamination study in the sandy beach of Libong Island, Trang province in May 2019, 44 microplastics were found in the sandy beach ecosystem with 31 microplastics smaller than $1 \mathrm{~mm}$ (Table 1). There were 13 pieces of microplastics with $1-5 \mathrm{~mm}$ size. For the mudflat area 8 pieces were found with 1$5 \mathrm{~mm}$ size. In the 2nd time, in July 2019, the total of 108 microplastics found in the sandy beach ecosystem consisted of 83 pieces of the most abundant microplastics with smaller than $1 \mathrm{~mm}$, followed by the microplastics larger than $5 \mathrm{~mm}$ and $1-5 \mathrm{~mm}$ which were 18 and 7 pieces, respectively, while in the mudflat area 15 pieces for size smaller than $1 \mathrm{~mm}$ were found.

The comparison of the number of microplastics 
Table 2 Microplastic found in sediment

\begin{tabular}{|c|c|c|c|c|}
\hline Location & Occurrence & Plastic type & Plastic size & Reference \\
\hline UK & Max 8 items $/ \mathrm{kg}$ & - & - & [19] \\
\hline Hong Kong & $\begin{array}{l}\text { Average abundance of } 5595 \\
\text { items } / \mathrm{m}^{2} \text { and maximum } \\
258408 \text { items } / \mathrm{m}^{2}\end{array}$ & Microplastic & 0.315 to $>5 \mathrm{~mm}$ & {$[26]$} \\
\hline Belgian Coast & $\begin{array}{l}\text { Average } 92.8 \text { items } / \mathrm{kg} \text { dry } \\
\text { sediment }\end{array}$ & Microplastic & $38 \mu \mathrm{m}$ to $1 \mathrm{~mm}$ & {$[10]$} \\
\hline $\begin{array}{l}\text { Gulf of Thailand, } \\
\text { Thailand }\end{array}$ & 248 items $/ \mathrm{kg}$ & Microplastic & $315 \mathrm{~lm}-5 \mathrm{~mm}$ & {$[28]$} \\
\hline $\begin{array}{l}\text { West beach of Phuket, } \\
\text { Thailand }\end{array}$ & 265 pieces $/ \mathrm{m}^{2}$ & Microplastic & - & [29] \\
\hline $\begin{array}{l}\text { Straits of Johor, } \\
\text { Malaysia }\end{array}$ & 300 items $/ \mathrm{kg}$ & Microplastic & $315 \mathrm{~lm}-5 \mathrm{~mm}$ & {$[28]$} \\
\hline $\begin{array}{l}\text { Libong Island, } \\
\text { Thailand }\end{array}$ & $\begin{array}{l}25 \text { pieces } / \mathrm{m}^{2} \text { (sandy beach) } \\
4 \text { pieces } / \mathrm{m}^{2} \text { (mudflat) }\end{array}$ & Microplastic & $\begin{array}{l}<1 \mathrm{~mm}, 1-5 \mathrm{~mm} \\
>5 \mathrm{~mm}\end{array}$ & This study \\
\hline
\end{tabular}

found in sediment in this study with other areas worldwide (Table 2) revealed that the number of microplastic found in this study (25 pieces $/ \mathrm{m}^{2}$ (sandy beach) and 4 pieces $/ \mathrm{m}^{2}$ (mudflat) was less than that from other areas such as 258408 items $/ \mathrm{m}^{2}$ found at Fan Lau Tung Wan, Hong Kong [26] and more than that of the Belgian Coast, 92.8 particles/kg dry sediment (assuming sediment sample in $1 \mathrm{~m}^{2}$ possessing $1 \mathrm{~kg}$ dry weight). This is because of the tourist activities of the Fan Lau Tung Wan beach whereas Libong Island is still natural beach. Kaberi et al [27] sampled on 6 beaches of Kea Island in the Aegean Sea. They sampled for microplastics larger than $2 \mathrm{~mm}$ and smaller than $4 \mathrm{~mm}$ in diameter. The abundance that they found ranged from 0 to 1218 items $/ \mathrm{m}^{2}$. Most microplastics and plastic pellets were made from PE and have undergone degradation. They identified the open sea as a source of microplastics for this island. When the amounts of microplastics were compared within Thailand $[28,29]$ and in Straits of Johor, Malaysia [28], the abundance of microplastics from this study was less than those of the aforementioned studies by several times.

The reason that other regions had more amounts of microplastics than those of Libong Island was probably explained by tourist activities of those other areas. The mainland also receives microplastic waste from community sewage whereas the island of Libong is still natural and located in non-hunting area. The community characteristics of the islanders are agricultural communities and awareness of nature conservation as well as the dangers of marine waste and microplastics and therefore they produce less waste than those with urban way of life, and tourism of Libong Island is still in its infancy. In the mud beach area, the amounts of microplastics found were much less than those of sandy beaches. This was probably caused by the microplastic transportation with current. Sea water brought the microplastics to accumulate in the sandy beach during the high tide, and therefore a lot of microplastics were found around the sandy beach. Another possible explanation was that some microplastics in the mud beach were consumed by the marine life such as molluscs, crabs, shrimp or even dugongs that might accidentally eat microplastics adhered to the leaves of seagrass since they misunderstood microplastics as their food, resulting in the less amounts of microplastics found in the mud beach than those of the sandy beach. Further study of this issue should be conducted.

\section{Plastic morphotypes, color and sizes}

Discovered microplastics were mainly constituted of fibers (59\%), followed by fragments (41\%) (Fig. 2). A great variety of colors were found, and white (43\% from beach, $41 \%$ from mudflat area) was the most common, followed by blue ( $9 \%$ from beach, $35 \%$ from mudflat) and red (12\% from beach, $6 \%$ from mudflat) (Fig. 3). The sources of the fragments are difficult to be tracked, but fibers are commonly produced by the degradation of textiles [13]. A range of marine biota, including seabirds, crus- 

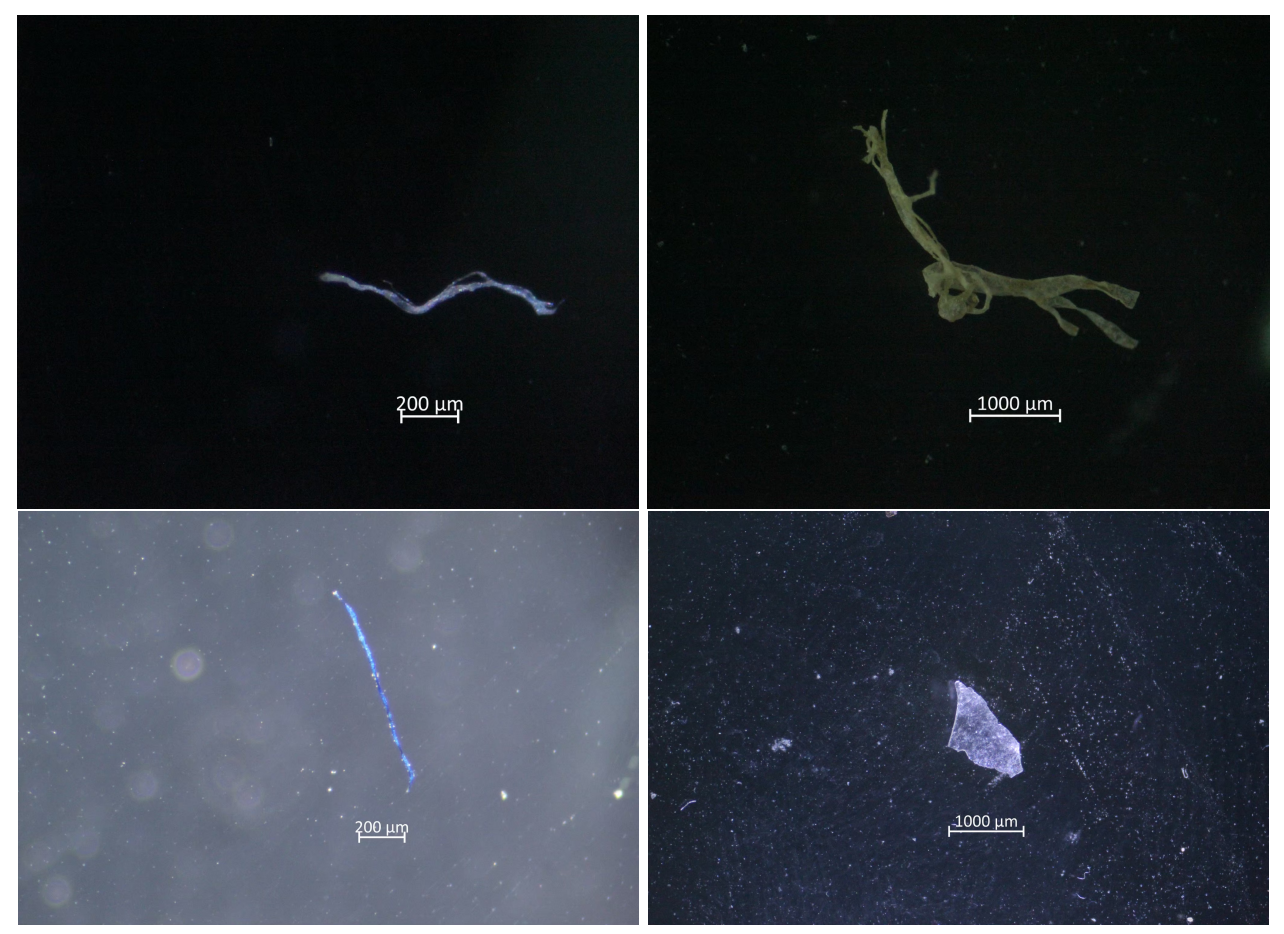

Fig. 2 Examples of microplastic found in sediment samples.

(a)

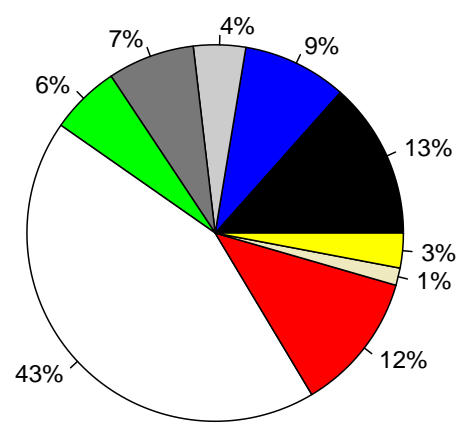

(b)

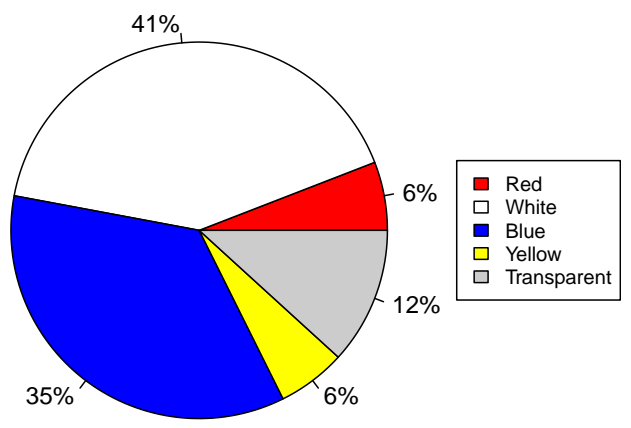

Fig. 3 Percentage of plastic color found from (a) sand beach sediment and (b) mudflat sediment. taceans and fishes, can ingest microplastics [30]. Plastic fragments were first identified in the guts of sea birds in the 1960s when global plastic production was less than 25 million tonnes per annum $[17,29]$. Plastic fibers were also found in the stomachs of mussels [22] and fishes [21] (pelagic fishes caught in the Gulf of Thailand). The colors of these particles are of importance since they could affect the likelihood of marine organisms ingesting them [31]. For instance, it was found that some fishes will consume more blue particles because they resemble the blue copepods that they usually feed on. Microplastic sizes found from this study were mainly smaller than $1 \mathrm{~mm}(61 \%)$, larger than $5 \mathrm{~mm}(18 \%)$ and $1-5 \mathrm{~mm}(13 \%)$. The sizes of particles also determine the likelihood of the sizes of marine organisms ingesting them. For example, the particles found in this study were relatively smaller than $1 \mathrm{~mm}$ and therefore may be available to small filter feeding organisms such as mussels and squids [21,22], and particle larger than $1 \mathrm{~mm}$ may be gulped by bigger fishes.

\section{Type of plastic}

The study area at village no. 7 of Libong Island revealed the microplastics with the highest fiber content contaminated in sandy beach and mudflat beach. The microplastic types found were poly 


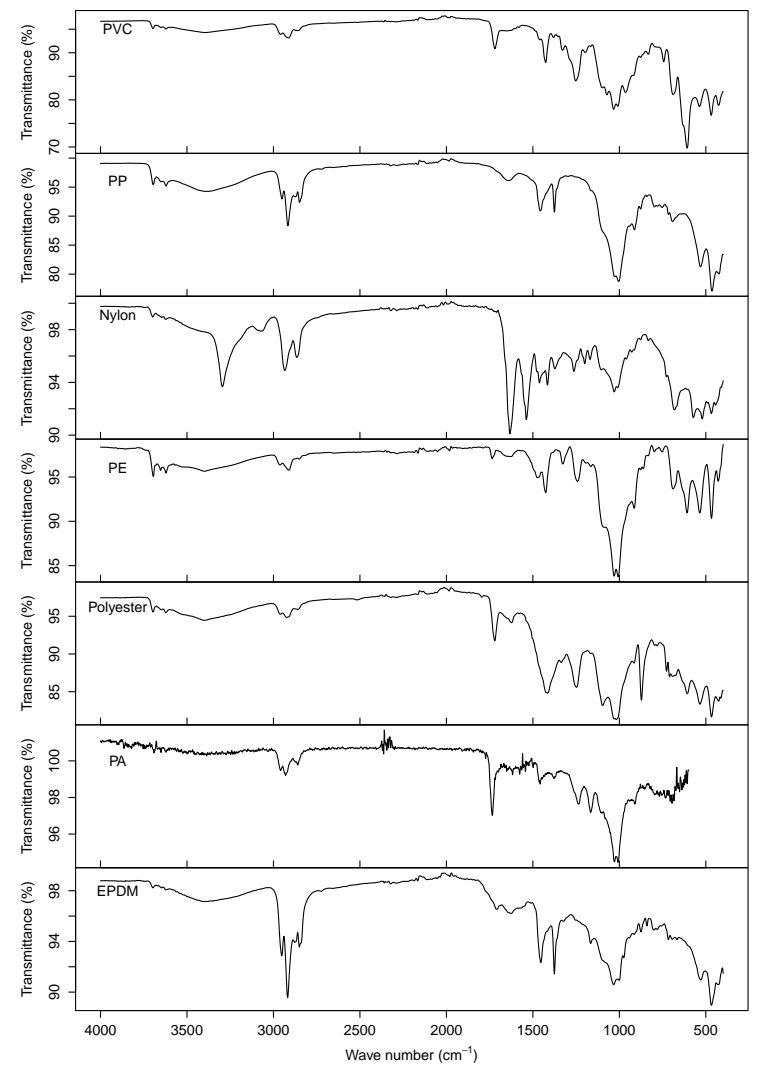

Fig. 4 Types of polymer detected in beach sediment at Libong Island: PVC, PP, Nylon, PE, Polyester, PA (polyacrylate) and EPDM.

vinyl chloride (PVC), polypropylene (PP), Nylon, Polyethylene (PE), Polyester, Polyacrylate (PA) and polymer with a structure similar to EPDM rubber (a blended polymer between ethylene and propylene), and another monomer was added to make a double bond in the polymer structure (Fig. 4).

In our result, 7 types of polymers were found by analyzing sediment samples whereas Thompson et al [19] found microplastics consisting of 9 different polymers in 23 samples out of 30 estuarine, beach and sub-tidal sediment samples taken around Plymouth, UK, including microscopic fibers and fragments typically derived from clothing, packaging and ropes. From this study, the result showed no polystyrene if compare our result with other beaches at Fah Lau Tung Wan, Hong Kong [26], from which over $90 \%$ of samples were classified as microplastics $(<5 \mathrm{~mm})$ with $92 \%$ of the microplastic being polystyrene. It may be because of the lifestyle of the people in Hong Kong using insulated boxes for takeaway food or food trans- portation [26], but the lifestyle of people on Libong Island is still the traditional way. Our result found Nylon and polypropylene (PP), which is the same as the study of Claessens et al [10] which investigated beach sediment along the Belgian Coast and found microplastic with fibers over $88 \%$. The polymers of the analyzed fibers were Nylon, poly vinyl alcohol and polypropylene (PP), which were mainly derived from fishing nets, carpets and ropes. Since the fishing is a common activity on the Libong Island and the fishing nets tend to become brittle, break down into small pieces and eventually degrade further when exposed to UV radiation either under direct sunlight or in seawater [32]. Apart from this, we found Polyester that was probably derived from textiles. The high abundance of PP can be explained by high production volumes and use, especially for packaging materials, and thus it has higher probability for becoming plastic litter. The study conducted by Lee et al [5] investigated the abundance of plastic in different seasons and found that the accumulation of plastic in beach sediment after the rainy season was higher than that before the rainy season. A great abundance of plastic items was observed on windward beaches as compared to leeward beaches [33].

From FTIR spectra in the Fig. 4, it was found that all the spectra show absorption peaks at wavenumber of $2800-3000 \mathrm{~cm}^{-1}$, which are referred to vibration of $-\mathrm{CH}$ stretching from the backbone structure of each polymer. Moreover, these spectra show a strong peak at $1000-1100 \mathrm{~cm}^{-1}$; it is possible that the absorption peak is affected by unremoved soil, sand or some other chemicals that are used in the polymers, but it cannot be identified by this technique. The spectrum of poly vinyl chloride (PVC) shows a strong absorption peak $\mathrm{C}-\mathrm{Cl}$ stretching close to $600 \mathrm{~cm}^{-1}$, methylene groups $\left(-\mathrm{CH}=\mathrm{C}\right.$ ) wagging at $1420 \mathrm{~cm}^{-1}$ and $-\mathrm{C}-\mathrm{H}$ stretching from $\mathrm{CH}-\mathrm{Cl}$ structure at $1257 \mathrm{~cm}^{-1}$. Moreover, it has a strong vibration peak at $1720 \mathrm{~cm}^{-1}$ that might be due to the characteristic of carbonyl band from phthalate plasticizer which is always used in PVC. For polypropylene (PP) spectrum, it is clearly seen the strong vibration peaks of $-\mathrm{CH}_{3}$ and $-\mathrm{CH}_{2}$ bending in the PP structure at $1450 \mathrm{~cm}^{-1}$ and $1376 \mathrm{~cm}^{-1}$, respectively [34]. Nylon spectrum shows a strong absorption peak of $-\mathrm{NH}$ stretching and $-\mathrm{NH}$ bending from its structure at wavenumber of $3290 \mathrm{~cm}^{-1}$ and $1535 \mathrm{~cm}^{-1}$, respectively. Furthermore, the absorption peak of $\mathrm{C}=\mathrm{O}$ stretching at $1630 \mathrm{~cm}^{-1}$ is a good evidence to prove the structure of Nylon. Basically Polyethylene (PE) has a simple 
structure because it is synthesized from only ethylene monomer $\left(\mathrm{CH}_{2}=\mathrm{CH}_{2}\right)$. From the FTIR spectra, $\mathrm{PE}$ structure has been confirmed by the presence of $-\mathrm{CH}$ bending at $1460 \mathrm{~cm}^{-1}$. The FTIR spectrum of Polyester clearly shows the absorption peak of $\mathrm{C}=\mathrm{O}$ at $1720 \mathrm{~cm}^{-1}$ and the vibration of $\mathrm{O}=\mathrm{C}-\mathrm{O}-\mathrm{C}$ at $965 \mathrm{~cm}^{-1}$ [35]. These are the characteristic peaks of Polyester. The structure of Polyacrylate (PA) is proved by the FTIR spectrum as the presence of carbonyl group vibration $(\mathrm{C}=\mathrm{O})$ at $1740 \mathrm{~cm}^{-1}$ and strong stretching bands of ester group from acrylate structure in the region of $1100-1300 \mathrm{~cm}^{-1}$ [36]. Ethylene-propylene-diene rubber (EPDM) is a synthetic rubber which has a chemical structure closed to PP structure. PP is a copolymer of propylene as a major phase and ethylene. It is observed that the FTIR structures of PP and EPMD are similar. However, EPDM spectrum shows some absorption peak of carbonyl group $(\mathrm{C}=\mathrm{C})$ at $1620 \mathrm{~cm}^{-1}$ from diene groups in EPDM structure [37]. Due to the fact that the FTIR of PP and EPDM are quite similar, it is not clearly confirmed by only FTIR technique. According to the sample appearance, the EPDM is softer and more elastic than PP sample. This helps to confirm the characteristic of EPDM.

Several broad classes of plastics are used in packaging: Polyethylene (PE), polypropylene (PP), polystyrene (PS), poly (ethylene terephthalate) (PET) and poly vinyl chloride (PVC); polyolefins (PE and PP) and Nylons are primarily used in fishing gear applications [38].

\section{CONCLUSION}

This is a first report of the study of polymer types present in beach sediment at Libong Island, which is a significant habitat of the endangered dugongs. Microplastics found in this study were composed of a variety of polymers including poly vinyl chloride (PVC), polypropylene (PP), Nylon, Polyethylene (PE), Polyester and Polyacrylate (PA). The size of microplastics was mainly smaller than $1 \mathrm{~mm}$ which might be consumed by small benthic organisms and dugongs living on the beach sediment. Therefore, they can contaminate the food chain and finally reach to humans and dugongs, as already happened to the death of the young dugong named Mariam caused by consuming some fragments of plastic bags in August 17th, 2019 at Libong Island. Hence, further studies should focus on investigating microplastic contamination in the marine organisms, sediment, sea grasses (dugong food) and also the current direction since it is currently a serious global problem waiting to be solved immediately.
Acknowledgements: This work was financially supported by Grand Challenges Thailand: Thai Ocean Waste Free, National Research Council of Thailand (Sub project: Marine litter and microplastic at Libong Island, Trang province). We would like to express our sincere thanks to the Department of National Parks, Wildlife and Plant Conservation for allowing us to conduct the research at Libong Island and Dr. Kanda Sengloyluan and Associate Professor Dr. Varaporn Tanrattanakul for FTIR analysis.

\section{REFERENCES}

1. UNEP (2016) Marine Plastic Debris and Microplastics: Global Lessons and Research to Inspire Action and Guide Policy Change. United Nations.

2. Geyer R, Jambeck JR, Law KL (2017) Production, use, and fate of all plastics ever made. Sci $A d v \mathbf{3}$, e1700782.

3. Van Cauwenberghe L, Claessens M, Vandegehuchte MB, Mees J, Janssen CR (2013) Assessment of marine debris on the Belgian Continental Shelf. Mar Pollut Bull 73, 161-169.

4. Claessens M, Van Cauwenberghe L, Vandegehuchte MB, Janssen CR (2013) New techniques for the detection of microplastics in sediments and field collected organisms. Mar Pollut Bull 70, 227-233.

5. Lee J, Hong S, Song YK, Hong SH, Jang YC, Jang M, Heo NW, Han GM, et al (2013) Relationships among the abundances of plastic debris in different size classes on beaches in South Korea. Mar Pollut Bull 77, 349-354.

6. Graham ER, Thompson JT (2009) Deposit-and suspension-feeding sea cucumbers (Echinodermata) ingest plastic fragments. J Exp Mar Bio Ecol 368, 22-29.

7. Betts K (2008) Why small plastic particles may pose a big problem in the oceans. Environ Sci Technol 42, 8995-8995.

8. Ryan PG, Moore CJ, van Franeker JA, Moloney CL (2009) Monitoring the abundance of plastic debris in the marine environment. Philos Trans R Soc B Biol Sci 364, 1999-2012.

9. Browne MA, Galloway TS, Thompson RC (2010) Spatial patterns of plastic debris along Estuarine shorelines. Environ Sci Technol 44, 3404-3409.

10. Claessens M, Meester S De, Landuyt L Van, Clerck K De, Janssen CR (2011) Occurrence and distribution of microplastics in marine sediments along the Belgian coast. Mar Pollut Bull 62 2199-2204.

11. Hidalgo-Ruz V, Gutow L, Thompson RC, Thiel M (2012) Microplastics in the marine environment: A review of the methods used for identification and quantification. Environ Sci Technol 46, 3060-3075.

12. Cole M, Lindeque P, Halsband C, Galloway TS (2011) Microplastics as contaminants in the marine environment: A review. Mar Pollut Bull 62, 2588-2597. 
13. Browne MA, Crump P, Niven SJ, Teuten E, Tonkin A, Galloway T, Thompson R (2011) Accumulation of microplastic on shorelines woldwide: sources and sinks. Environ Sci Technol 45, 9175-9179.

14. Lusher AL, Tirelli V, O'Connor I, Officer R (2015) Microplastics in Arctic polar waters: the first reported values of particles in surface and sub-surface samples. Sci Rep 5, ID 14947.

15. Piehl S, Mitterwallner V, Atwood EC, Bochow M, Laforsch C (2019) Abundance and distribution of large microplastics (1-5 mm) within beach sediments at the Po River Delta, northeast Italy. Mar Pollut Bull 149, ID 110515.

16. Rios LM, Moore C, Jones PR (2007) Persistent organic pollutants carried by synthetic polymers in the ocean environment. Mar Pollut Bull 54, 1230-1237.

17. Thompson RC, Swan SH, Moore CJ, vom Saal FS (2009) Our plastic age. Philos Trans R Soc B Biol Sci 364, 1973-1976.

18. Barnes DKA, Galgani F, Thompson RC, Barlaz M (2009) Accumulation and fragmentation of plastic debris in global environments. Philos Trans $R$ Soc $B$ Biol Sci 364, 1985-1998.

19. Thompson RC (2004) Lost at sea: Where is all the plastic? Science 304, 838-838.

20. Andrady AL, Neal MA (2009) Applications and societal benefits of plastics. Philos Trans R Soc B Biol Sci 364, 1977-1984.

21. Wirachwong P, Holmer M (2010) Nutrient dynamics in 3 morphological different tropical seagrasses and their sediments. Aquat Bot 93, 170-178.

22. Adulyanukoson K, Thongsookde S (2006) Monioring of Dukong at Muk and Libong Island, Trang Province, Thailand. [in Thai]

23. Lippiatt S, Opfer S, Arthur C (2013) Marine Debris Monitoring and Assessment: Recommendations for Monitoring Debris Trends in the Marine Environment. NOAA Technical Memorandum NOS-OR\&R46.

24. Fok L, Cheung PK (2015) Hong Kong at the Pearl River Estuary: A hotspot of microplastic pollution. Mar Pollut Bull 99, 112-118.

25. Kaberi H, Tsangaris C, Zeri C, Mousdis G, Papadopoulos A, Streftaris N (2013) Microplastics along the shoreline of a Greek island (Kea isl., Aegean Sea): types and densities in relation to beach orientation, characteristics and proximity to sources. In: 4th International Conference on Environmental Management, Engineering, Planning and Economics (CEMEPE) and SECOTOX Conference, pp 197-202.

26. Matsuguma $Y$, Takada H, Kumata H, Kanke H, Sakurai S, Suzuki T, Itoh M, Okazaki Y, et al (2017) Microplastics in sediment cores from Asia and Africa as indicators of temporal trends in plastic pollution. Arch Environ Contam Toxicol 73, 230-239.

27. Ekkachit P, Ruamkaew S (2019) Microplastic on West Beach of Phuket. Environ J 23, 1-8.

28. Tourinho PS, Ivar do Sul JA, Fillmann G (2010) Is marine debris ingestion still a problem for the coastal marine biota of southern Brazil? Mar Pollut Bull 60, 396-401.

29. Goh P, Pradit S, Towatana P, Khokkiatiwong S, Azad S (2019) Microplastics in green mussel Perna viridis from Singhanakorn district, Songkhla province, Thailand. In: Proc of the 34th AUAP Annual Conference 2019 Climate Change Adaptation The Challenging Role of Higher Education Institutions, Naresuan University, Phitsanulok, pp 19-23.

30. Azad SMO, Towatana P, Pradit S, Goh PB, Hue HTT, Jualaong S (2018) First evidence of existence of microplastics in stomach of some commercial fishes in the lower Gulf of Thailand. Appl Ecol Environ Res 16, 7345-7360.

31. Ory NC, Sobral P, Ferreira JL, Thiel M (2017) Amberstripe scad Decapterus muroadsi (Carangidae) fish ingest blue microplastics resembling their copepod prey along the coast of Rapa Nui (Easter Island) in the South Pacific subtropical gyre. Sci Total Environ 586, 430-437.

32. Moore CJ (2008) Synthetic polymers in the marine environment: A rapidly increasing, long-term threat. Environ Res 108, 131-139.

33. Ivar do Sul JA, Spengler Â, Costa MF (2009) Here, there and everywhere. Small plastic fragments and pellets on beaches of Fernando de Noronha (Equatorial Western Atlantic). Mar Pollut Bull 58, 1236-1238.

34. Chun KS, Husseinsyah S, Osman H (2012) Modified cocoa pod husk-filled polypropylene composites by using methacrylic acid. BioResources 8, 3260-3275.

35. Bhattacharya S, Chaudhari SB (2014) Study on structural, mechanical and functional properties of polyester silica nanocomposite fabric. Int J Pure Appl Sci Technol 21, 43-52.

36. Ma H, Tian Y, Li Z (2011) Interactions between organic and inorganic phases in PA-and PU/PAmodified-cement-based materials. J Mater Civil Eng 23, 1412-1421.

37. Mokhothu TH, Luyt, AS, Messori M (2014) Preparation and characterization of EPDM/silica nanocomposites prepared through non-hydrolytic sol-gel method. Express Polym Lett 8, 809-822.

38. Timmers M, Kistner C, Donohue M (2005) Marine Debris of the Northwestern Hawaiian Islands: Ghost Net Identification, Honolulu. 